Postgraduate Bosowa University Publishing (PBUP)
Indonesian Journal of Business and Management
e-ISSN: $2460-3767 \quad p$-ISSN: $2656-6885$
INttps://postgraduate.universitasbosowa
JOURAL

\title{
PENGARUH PENGETAHUAN, KEMAMPUAN BERPIKIR, ANALISIS TUGAS, PENGALAMAN, TEKANAN WAKTU TERHADAP PENDETEKSIAN KECURANGAN OLEH INSPEKTORAT KABUPATEN PINRANG
}

\author{
The Influence of Knowledge, Thinking Skill, Task Analysis, Experience, Time Pressure on the Detection \\ of Fraud by the Inspectorate of Pinrang Regency \\ Asriadi $^{1}$, Firman Menne ${ }^{2}$, Lukman Setiawan ${ }^{2}$ \\ ${ }^{1}$ Ispektorat Pemenrintah Kabupaten Pinrang \\ ${ }^{2}$ Program Studi Manajemen Program Pascasarjana Universitas Bosowa \\ Email: asriadi9911@gmail.com
}

Diterima: 22 Januari 2021/Disetujui: 02 Juni 2021

\begin{abstract}
ABSTRAK
Penelitian ini untuk mengetahui Pengaruh Pengetahuan, Kemampuan Berpikir, Analisis Tugas, Pengalaman, Tekanan Waktu Terhadap Pendeteksian Kecurangan Oleh Inspektorat Kabupaten Pinrang. Analisis yang digunakan adalah analisis regresi linear berganda dengan model uji $t$ dan uji F. Dari hasil pengujian regresi linear berganda diketahui bahwa pengetahuan berpengaruh positif dan signifikan terhadap pendeteksi kecurangan. Kemampuan berpikir berpengaruh positif dan signifikan terhadap pendeteksi kecurangan. Analisis tugas berpengaruh positif dan signifikan terhadap pendeteksi kecurangan. Pengalaman berpengaruh positif dan signifikan terhadap pendeteksi kecurangan. Tekanan waktu berpengaruh positif dan signifikan terhadap pendeteksi kecurangan. Hal ini menjadi bukti empiric bahwa indikator-indikator yang digunakan dalam penelitian ini dapat digunakan sebagai alat untuk pendeteksian kecurangan di Inspektorat Kabupaten Pinrang. Dari hasil uji regresi dapat dilihat bahwa variabel pengetahuan, kemampuan berpikir, analisis tugas, pengalaman, tekanan waktu yang lebih kuat mempengaruhi pendeteksian kecurangan oleh Inspektorat Kabupaten Pinrang.
\end{abstract}

Kata Kunci: Pengetahuan; Kemampuan Berpikir; Analisis Tugas; Pengalaman; Tekanan Waktu; Pendeteksi Kecurangan

\begin{abstract}
This study is to determine the influence of Knowledge, Thinking Skill, Task Analysis, Experience, Time Pressure and Detection of Fraud in the Inspectorate of Pinrang Regency. The analysis used is multiple linear regression analysis with the t-test and F-test models. From the results of multiple linear regression test, it is known that knowledge has a positive and significant effect on fraud detection. Thinking skill has a positive and significant effect on fraud detection. Task analysis has a positive and significant effect on fraud detection. Experience has a positive and significant effect on fraud detection. Time pressure has a positive and significant effect on fraud detection. This is empiric evidence that the indicators used in this study can be used as a tool for detecting fraud in the Inspectorate of Pinrang Regency. From the results of the regression test, it can be seen that the variables of knowledge, thinking skill, task analysis, experience, stronger time pressure affect the detection of fraud in the Inspectorate of Pinrang Regency.
\end{abstract}

Keywords: Knowledge; Thinking Skill; Task Analysis; Experience; Time Pressure; Fraud Detection

\section{PENDAHULUAN}

Perkembangan era globalisasi seperti sekarang ini, banyak aktivitas yang tidak dapat terlepas dari praktek kecurangan atau fraud. Kecurangan bisa saja dilakukan oleh perseorangan, tetapi bisa juga dilakukan oleh sekelompok orang di dalam organisasi yang bekerja sama dalam praktek kecurangan. Meningkatnya kasus skandal akuntansi menyebabkan berbagai pihak berspekulasi bahwa manajemen telah melakukan kecurangan pada laporan keuangan.

Kecurangan (fraud) adalah merupakan tindakan kriminal (crime) yang dilakukan secara sengaja oleh 
seseorang atau beberapa orang berupa kecurangan/ ketidak beresan (irregularities) atau penipuan yang melanggar hukum (illegal act) untuk mendapatkan keuntungan atau mengakibatkan kerugian suatu organisasi (perusahaan). Pengetahuan dan keahlian mengenai fraud auditing menjadi kebutuhan mendesak bagi auditor internal yang mengharapkan pelaksanaan audit atas fraud dapat berjalan denganlancar.

Wardani (2014) menyatakan faktor lain pemicu terjadinya kecurangan adalah lemahnya pengendalian intern terhadap sumber daya manusia di suatu perusahaan. Hal tersebut dapat terjadi karena keterbatasan komunikasi antara manajer puncak dengan lini operasional perusahaan. Keterbatasan komunikasi ini menyebabkan kecurangan, contohnya pencurian data, pemalsuan, penggelapan, dan pemerasan. Lebih parah lagi jika pelaku merupakan orang yang memiliki kekuasaan di perusahaan. Hal ini akan berakibat fatal bagi perusahaan jika sumber daya manusia di dalamnya merupakan pegawai yang akan menjatuhkan perusahaan itu demi kepentingan mereka sendiri. Timbulnya masalah kecurangan akan menurunkan nilai suatu perusahaan. Ini menjelaskan betapa pentingnya peran auditor dalam mendeteksi terjadinya kecurangan atau fraud.

Internal auditor selaku orang yang melakukan pemeriksaan memiliki beberapa peran (Marpaung, 2004) yaitu (1) Pencegahan Kecurangan (Fraud Prevention) (2) Pendeteksian Kecurangan (Fraud Detection), dan (3) Penginvestigasian Kecurangan (Fraud Investigation). Ada tiga bentuk kecurangan, antara lain: Pertama, penyalahgunaan atas aset adalah kecurangan yang melibatkan pencurian aktiva entitas. Kedua, pernyataan palsu atas laporan keuangan salah saji atau pengabaian jumlah atau pengungkapan yang disengaja dengan maksud menipu para pemakai laporan keuangan itu. Ketiga, korupsi penyalahgunaan jabatan di sektor pemerintah untuk keuntungan pribadi (Tuannakotta, 2007). Bentuk kecurangan tersebut yang harus dicegah supaya tidak terjadi atau setidaktidaknya dapat mengurangi adanya tindakan kecurangan.

Pencegahan fraud di sektor publik dilakukan dengan mengeluarkan berbagai peraturan perundang-undangan, yang menetapkan berbagai sanksi yang diharapkan dapat menangkal atau setidak-tidaknya dapat mengurangi tindak fraud. Menurut penelitian Wardani (2014) bahwa untuk menjamin berjalannya proses pengendalian internal yang baik dalam suatu organisasi, di mana aktivitas audit internal dapat menekan 35\% fraud. Oleh karena itu peran Audit internal sangat diperlukan, karena audit internal merupakan suatu bagian yang independen, yang disiapkan untuk menjalankan fungsi pemeriksaan, pengendalian dan keberadaan audit internal ditunjukkan untuk memperbaiki kinerja organisasi.

Peran seorang internal auditor sangat penting, karena dengan serangkaian pemeriksaan yang dilakukannya, maka meningkatkan pengendalian dan proses tata kelola (Boynton, 2001) dengan tugas dan wewenang yang dimiliki internal auditor dapat berperan dalam pendeteksian kecurangan pada lembaga di mana ia bekerja. Oleh karena itu, untuk dapat mendeteksi terjadinya kecurangan internal auditor maka perlunya diperhatikan beberapa faktor untuk mendeteksi kecurangan melalui komponen keahlian yang dimiliki oleh seorang auditor yang terdiri dari: pengalaman, pengetahuan, kemampuan berpikir, analisis tugas serta tekanan waktu berpengaruh dalam mendeteksi terjadinya fraud atau kecurangan.

Variabel komponen keahlian dan tekanan waktu di atas mendukung peranan atau sikap auditor dalam mendeteksi kecurangan. Menurut Bonner \& Lewis (1990) pengetahuan dan kemampuan menyelesaikan masalah merupakan kriteria penting dalam keahlian kinerja auditor. Kedua keahlian ini bisa menjadi kekuatan seorang auditor dalam menyelesaikan masalah kecurangan. Dengan adanya pengetahuan baru, pengalaman baru serta kuatnya kemampuan dalam menyelesaikan masalah akan besar peluang bagi auditor dalam mengatasi masalah kecurangan.

Pengawasan pada lingkup pemerintahan dilakukan oleh Aparat Pengawas Intern Pemerintah (APIP) seperti Badan Pengawas Keuangan dan Pembangunan (BPKP), Inspektorat Jenderal Departemen, Inspektorat/unit pengawasan intern pada Kementerian Negara, Inspektorat Utama/Inspektorat Lembaga Pemerintah Non Departemen, Inspektorat/unit pengawasan intern pada Kesekretariatan Lembaga Tinggi Negara dan Lembaga Negara, Inspektorat Provinsi/Kabupaten/Kota. APIP sebagaimana disebut di atas dikenal istilah auditor, yaitu jabatan yang mempunyai ruang lingkup, tugas, tanggungjawab, dan wewenang untuk melakukan pengawasan intern pada instansi pemerintah, lembaga dan/atau pihak lain yang di dalamnya terdapat kepentingan negara sesuai dengan peraturan perundangundangan, yang diduduki oleh Pegawai Negeri Sipil dengan hak dan kewajiban yang diberikan secara penuh oleh pejabat yangberwenang.

Pada Standar Audit BPKP (2008) menyatakan bahwa seorang pengawas intern pemerintah atau yang berprofesi sebagai auditor maka dituntut untuk memiliki keahlian khusus yang tidak dimiliki oleh orang lain atau kebanyakan. Selain itu para auditor atau anggota profesi dituntut untuk memberikan hasil pekerjaan yang memuaskan karena ada kompensasi berupa pembayaran untuk melakukannya, sehingga mewajibkan adanya komitmen terhadap kualitas hasil pekerjaan.

Begitu pula dalam Standar audit bahwa seorang auditor internal pemerintah dalam menjalankan tugasnya harus berpedoman pada Standar audit yang ditetapkan oleh Menteri Pendayagunaan Aparatur Negara (Menpan) Nomor PER/M.PAN/03/2008 tentang Standar Audit Aparat Pengawas Intern Pemerintah. Ketentuan dalam standar umum disebutkan bahwa auditor harus mempunyai pengetahuan, keterampilan, dan kompetensi lainnya yang diperlukan untuk melaksanakan tanggung-jawabnya. Seorang auditor dituntut memiliki kemampuan profesioal yang tinggi yaitu dapat mengkombinasikan pengalaman dan kemampuan teknis/analisis yang cukup baik untuk memahami dan mencari solusi terhadap permasalahan yang timbul pada saat pemeriksaan. Kemampuan kerja audit pemeriksa internal memengaruhi kualitas hasil pemeriksaan yang telah dilaksanakan dalam hal ini adalah kemampuan pendeteksian temuan. 
Kualitas hasil audit dari seorang auditor antara lain dipengaruhi oleh keahlian yang dimiliki seorang audit. Seorang auditor harus mempunyai pengetahuan yang tinggi dalam bidang audit. Pengetahuan ini bisa didapat dari pendidikan formal yang diperluas dan ditambah antara lain melalui pelatihan auditor dan pengalaman-pengalaman dalam praktik audit. Kemudian kemampuan berpikir berpengaruh terhadap pendeteksian kecurangan, hal ini dikarenakan dengan adanya kemampuan yang dimiliki oleh seorang auditor maka segala permasalahan yang terjadi mengenai adanya fraud dapat diselesaikan sampai tuntas (Wardani, 2014).

Kredibilitas seorang auditor harus terjaga, untuk itu auditor harus selalu meningkatkan kemampuan dan keahliannya ketika menjalankan tugasnya. Kondisi tentang keahlian ini semakin dirasakan semakin pentingnya manakala berhadapan dengan kecurangan yang terjadi sedemikian kompleks dan informan yang diinterogasi terkesan berusaha menutup-nutupi sesuatu dan tidak konsisten dalam memberikan keterangan.

Selanjutnya analisis tugas adalah berkaitan dengan proses menganalisa mengenai cara melakukan dan menyelesaikan tugas audit yang dilakukan dengan obyek yang ada dan terjadi, sehingga analisis tugas ini memberikan pemahaman bagi auditor internal untuk menyelesaikan masalah yang terjadi. Hal ini sesuai dengan penelitian yang dilakukan oleh Pratiwi (2010) bahwa analisis tugas ini akan mempunyai pengaruh terhadap penentuan keputusan. Kompleksitas tugas akan mempengaruhi pilihan terhadap bantuan keputusan oleh auditor yang telah tinggi pengalamannya dan digunakan untuk mengembangkan kerangka umum dari lingkungan tugas dalam auditing.

Laporan Hasil Pemeriksaan (LHP) yang dibuat oleh auditor intern akan tergambar dengan baik (tidak bias) jika auditor memahami analisis tugas dengan baik. Analisis tugas ini cukup penting karena akan menggambarkan kondisi obyek pemeriksaan, jika analisis tugas (metode audit yang digunakan) kurang baik maka LHP yang dihasilkan juga kurang baik. LHP yang kurang baik menyebabkan kecurangan/penyimpangan yang terjadi tidak jelas.

Faktor komponen keahlian lainnya yang berpengaruh dalam mendeteksi kecurangan adalah pengalaman. Pengalaman kerja telah dipandang sebagai suatu faktor penting dalam memprediksi kinerja auditor, sehingga pengalaman dimasukkan sebagai salah satu persyaratan dalam memperoleh izin menjadi akuntan publik di Indonesia. Kematangan auditor dalam melakukan audit tidak hanya ditentukan oleh pengetahuan yang diperoleh selama pendidikan namun juga tidak kalah pentingnya adalah pengalaman yang diperoleh selama melakukan pemeriksaan keuangan.

Hal ini tentu tidak mengherankan apabila cara memandang dan menanggapi informasi yang diperoleh selama melakukan pemeriksaan antara auditor yang berpengalaman dan yang kurang berpengalaman berbeda. Auditor yang berpengalaman diyakini mampu mendeteksi kecurangan karena pengalamannya dalam menghadapi berbagai peristiwa yang wajar maupun tidak wajar.
Selanjutnya tekanan waktu berpengaruh terhadap kemampuan auditor dalam mendeteksi terjadinya kecurangan atau fraud, hal ini disebabkan karena tekanan waktu adalah ciri lingkungan yang biasa dihadapi auditor. Sososutikno (2003) mengemukakan tekanan anggaran waktu adalah situasi yang ditunjukan untuk auditor dalam melaksanakan efisiensi terhadap waktu yang telah disusun atau terdapat pembatasan waktu dan anggaran yang sangat ketat dan kaku. Adanya tekanan waktu akan membuat auditor memiliki masa sibuk karena menyesuaikan tugas yang harus diselesaikan dengan waktu yang tersedia. Masalah akan timbul jika ternyata waktu yang direncanakan tidak sesuai dengan waktu yang dibutuhkan sebenarnya.

Hal yang paling menonjol tentang profesi auditor adalah tingkat stress yang tinggi karena bekerja di bawah tekanan. Menurut McGrath dalam Bowrin dan King II (2009), stress sebenarnya sangat dibutuhkan dalam 2 efektivitas pekerjaan. Saat tingkat stress terlalu rendah maka efektivitas kerja juga cenderung rendah karena tidak adanya faktor pendorong semangat kerja. Pada stress tingkat sedang, faktor pendorong akan berada dalam level yang optimal dan meningkatkan efektifitas kerja. Sedangkan pada tingkat stress yang terlalu tinggi maka efektivitas kerja akan menurun karena auditor merasa takut dan terlalu kuatir tidak dapat memenuhi target yang harus dicapai.

Alokasi waktu diberikan dalam suatu pemeriksaan bertujuan untuk mengurangi biaya audit. Semakin cepat waktu pengerjaan audit, maka biaya pelaksanaan audit akan semakin kecil. Keberadaan alokasi waktu ini memaksa auditor untuk menyelesaikan tugas secepatnya atau sesuai dengan alokasi waktu yang telah ditetapkan. Pelaksanaan prosedur audit seperti ini tentu saja tidak akan sama hasilnya bila prosedur audit dilakukan dalam kondisi tanpa anggaran waktu. Agar menepati anggaran waktu yang telah ditetapkan, ada kemungkinan bagi auditor untuk melakukan pengabaian terhadap prosedur audit bahkan pemberhentian prosedur audit (Silaban, 2011).

Obyek penelitian dalam penulisan ini adalah pada Kantor Inspektorat Kabupaten Pinrang, sebagai Instansi atau badan pengawas daerah dengan visi yakni Inspektorat Kabupaten Pinrang professional dalam pelaksanaan pengawasan menuju terwujudnya aparatur yang taat pada peraturan perundang-undangan. Sedangkan misinya adalah meningkatkan pengawasan pada semua sektor kegiatan pemerintahan, meningkatkan kemampuan pengawas melalui pendidikan dan pelatihan, meningkatkan kualitas produktivitas hasil pengawasan, meningkatkan pemantauan tindak lanjut hasil pengawasan, serta mensosialisasikan pengawasan pada Instansi/Unit Kerja dalam Lingkup Pemerintah Kabupaten Pinrang.

Sumber daya manusia yang berkualitas sangat dibutuhkan untuk mencapai visi dan misi Inspektorat Kabupaten Pinrang, maka diharapkan kinerja tinggi dari setiap pegawai melalui kemampuan dan ketrampilan yang tinggi dalam mengemban tugas pokok dan fungsinya dalam upaya mewujudkan aparat di Kabupaten Pinrang yang taat pada peraturan, maka peran dan fungsi pengawas intern pemerintah sangat diperlukan, karena fenomena yang terjadi 
pada kantor Inspektorat bahwa tingkat kecurangan (fraud) masih dianggap tinggi, di mana salah satu kecurangan yang terjadi saat ini yaitu adanya tingkat penyelewengan keuangan yang terjadi pada organisasi, maka dibutuhkan keahlian pengawas intern pemerintahan dalam mendeteksi terjadinya kecurangan, dimana fenomena yang terjadi bahwa semakin meningkatnya kasus fraud yang terjadi.

Data hasil pemeriksaan (BPK, 2019) pada semester I tahun 2019 menyebutkan bahwa terdapat sejumlah kasus temuan pada kabupaten/kota di Sulawesi Selatan, antara lain sebagai berikut; Bantaeng 22 kasus, Barru 21 kasus, Bone 24 kasus, Gowa 27 kasus, Jeneponto 39 kasus, Palopo 24 kasus, Takalar 40 kasus, Selayar 40 kasus, Makassar 47 kasus, Pare-Pare 39 kasus. Laporan hasil pemeriksaan pada Kabupaten Pinrang sendiri adalah sebagai berikut:

Tabel 1. Data Laporan Hasil Pemeriksaan Inspektorat Kabupaten Pinrang

\begin{tabular}{ccccc}
\hline Tahun & LHP & Temuan & $\begin{array}{c}\text { Persentase } \\
\text { Temuan }\end{array}$ & Keterangan \\
\hline 2014 & 139 & 26 & 18,71 & Kerugian daerah \\
2015 & 142 & 13 & 9,15 & Kerugian daerah \\
2016 & 144 & 6 & 4,17 & Kerugian daerah \\
2017 & 145 & 25 & 17,24 & Kerugian daerah \\
\hline
\end{tabular}

Sumber: Kantor Inspektorat Kabupaten Pinrang (2019)

Data pada Tabel 1 di atas terlihat bahwa jumlah laporan hasil pemeriksaan (LHP) maupun temuan dari tahun 2014 hingga 2017 tidak menunjukan penurunan yang signifikan. Adapun jumlah temuan yang didapatkan merupakan fraud yang menyebabkan timbulnya kerugian daerah.

Pengamatan awal yang penulis lakukan di Inspektorat Kabupaten Pinrang menunjukan bahwa hal-hal berikut ini seperti pengetahuan, kemampuan berpikir, analisis tugas, pengalaman auditor serta aspek tekanan waktu dalam penyelesaian tugas auditor itu sendiri dapat mempengaruhi auditor dalam mendeteksi terjadinya kecurangan atau fraud. Beberapa aspek yang penulis sebut di atas (pengetahuan, kemampuan berpikir, analisis tugas, pengalaman serta tekanan waktu) juga dijadikan sebagai variabel penelitian oleh peneliti-peneliti sebelumnya sebagaimana diuraikan di bawahini.

Penelitian ini replikasi dari penelitian yang dilakukan oleh Harold Hassink (2010) meneliti mengenai Fraud detection, redress and reporting by auditor. penelitian yang dilakukan oleh Pertiwi (2010) Penelitian internasional yang dilakukan oleh Indriasih (2013) yang berjudul: the effect of government Apparatus Competence and the Effectiveness of Government Internal Control Towards the Quality of Financial Reporting in Local Government, dengan mengambil variabel kompetensi aparatur melalui pengetahuan dan pengalaman. Wardani (2014) yang meneliti mengenai pengaruh komponen keahlian auditor dalam mendeteksi kecurangan (studi empiris pada Eksternal Auditor di Semarang). Persamaan penelitian ini adalah pada variabel bebas yang diteliti, yakni pengetahuan, kemampuan berpikir, analisis tugas dan pengalaman. Untuk membedakan dari kedua penelitian tersebut di atas, maka penulis menambahkan variabel tekanan waktu dengan mengacu pada penelitian Angriawan (2014).

Hasil penelitian menunjukkan bahwa Karakteristik penipuan (yaitu materi terhadap penipuan immaterial, manajemen terhadap penipuan karyawan, hukum terhadap pemeriksaan sukarela dan eksternal dibandingkan internal fraud serta dengan auditor (pengalaman) dan karakteristik perusahaan audit (Big Fourversus non-Big Four).

\section{METODE}

Jenis penelitian yang akan digunakan adalah penelitian asosiatif (hubungan) dengan metode analisis kuantitatif (data berbentuk angka). Penelitian asosiatif merupakan penelitian yang bertujuan untuk mengetahui hubungan antara dua variabel atau lebih. Penelitian ini mempunyai tingkatan yang tertinggi bila dibandingkan dengan penelitian deskripstif dan komparatif. Dengan penelitian ini maka akan dapat dibangun suatu teori yang dapat berfungsi untuk menjelaskan, meramalkan dan mengontrol suatu gejala. Populasi yang digunakan dalam penelitian ini adalah pengawai Inspektorat Kabupaten Pinrang sebanyak 65 orang. Sampel adalah bagian dari populasi yang hendak diteliti, pengambilan sampel dalam penelitian ini menggunakan metode Purposive Sampling untuk mengetahui populasi yang mana ingin diteliti dan kemudian menggunakan metode Simple Random Sampling yang artinya semua populasi memilik kesempatan yang sama dipilih sebagai sampel.

\section{HASIL DAN PEMBAHASAN}

a. Uji Reabilitas

Uji realibilitas digunakan untuk mengetahui apakah indikator atau kuesioner yang digunakan dapat dipercaya atau handal sebagai alat ukur variabel. Realibilitas suatu indikator atau kuesioner dapat dilihat dari nilai cronbach's alpha $(\alpha)$, dimana menurut Sugiono (2016) bahwa suatu konstruk atau indikator dikatakan realibel yaitu apabila nilai cronbach's alpha $(\alpha)$ lebih besar (>) 0,60 maka indikator atau kuesioner adalah realible, sedangkan apbila nilai cronbach's alpha $(\alpha)$ lebih kecil (<) 0,60 maka indikator atau kuesioner tidak realible. Secara keseluruhan uji realibilitas dapat dilihat hasilnya pada tabel berikut ini:

Tabel 2. Hasil Pengujian Reabilitas.

\begin{tabular}{lcccc}
\hline \multicolumn{1}{c}{ Variabel } & $\begin{array}{c}\text { N of } \\
\text { Items }\end{array}$ & $\begin{array}{c}\text { Cronbach's } \\
\text { Alpha }\end{array}$ & $\mathrm{r}_{\text {tabel }}$ & Keputusan \\
\hline $\begin{array}{l}\text { Pengetahuan } \\
\text { Kemampuan }\end{array}$ & 5 & 0,211 & 0,24 & Reliabel \\
$\begin{array}{l}\text { Berpikir } \\
\text { Analisis tugas }\end{array}$ & 5 & 0,839 & 0,24 & Reliabel \\
Pengalaman & 5 & 0,720 & 0,24 & Reliabel \\
$\begin{array}{l}\text { Tekanan waktu } \\
\text { Pendeteksian }\end{array}$ & 5 & 0,890 & 0,24 & Reliabel \\
kecurangan & 5 & 0,615 & 0,24 & Reliabel \\
\hline Sumber: Data primer & 5 & 0,607 & 0,24 & Reliabel \\
\hline
\end{tabular}

Sumber: Data primer tahun 2020 diolah melalui SPSS V.21

Nilai cronbach's alpha semua variabel yang ditunjukan tabel diatas, yaitu pengetahuan, kemampuan 
berpikir, analisis tugas, pengalaman, tekanan waktu dan pendeteksi kecurangan. lebih besar dari nilai standar realibilitas yaitu lebih besar dari 0,24 Sehingga dapat disimpulkan bahwa indikator atau kuesioner semua variabel handal atau dapat digunakan sebagai alat ukur.

b. Uji Validasi

Pengujian validasi data dilakukan untuk mengetahui sejauh mana ketepatan alat ukur dapat mengungkapkan gejala atau kejadian yang di ukur. Validasi konstruk dalam penelitian ini diuji dengan menggunakan bivariate person (korelasi product momen person), dimana menurut Sugiono (2016) adalah cara yang dilakukan dengan mengkorelasikan masing-masing item dengan nilai total penjumlahan keseluruhan item yang diolah menggunakan program SPSS, dimana dikatakan valid apabila memiliki nilai corrected item total correlation melebihi atau di atas dari 0,30 .

Secara statistic angka korelasi yang diperoleh harus diuji terlebih dahulu untuk menyatakan apakah nilai korelasi yang dihasilkan signifikan atau tidak. Jika angka korelasi yang diperoleh di bawah atau kurang dari 0,30 maka pernyataan tersebut tidak valid atau tidak konsisten dengan pernyataan yang lain, sedangkan apabila di atas atau melebihi dari 0,30 berarti indikator yang digunakan sudah valid. Untuk hasil lengkap dari uji validasi atas komunikasi interpresional, beban kerja kepuasan kerja, dan produktifitas dapat dilihat pada tabel berikut:

Tabel 3. Hasil Pengujian Validasi

\begin{tabular}{|c|c|c|c|}
\hline $\begin{array}{c}\text { Butir } \\
\text { Pertanyaan }\end{array}$ & $\mathrm{r}_{\text {hitung }}$ & $\mathrm{r}_{\text {tabel }}$ & Keterangan \\
\hline $\mathrm{X}_{1.1}$ & 0,458 & 0,24 & Valid \\
\hline $\mathrm{X}_{1.2}$ & 0,390 & 0,24 & Valid \\
\hline $\mathrm{X}_{1.3}$ & 0,798 & 0,24 & Valid \\
\hline $\mathrm{X}_{1.4}$ & 0,257 & 0,24 & Valid \\
\hline $\mathrm{X}_{1.5}$ & 0,460 & 0,24 & Valid \\
\hline $\mathrm{X}_{2.1}$ & 0,736 & 0,24 & Valid \\
\hline $\mathrm{X}_{2.2}$ & 0,655 & 0,24 & Valid \\
\hline $\mathrm{X}_{2.3}$ & 0,819 & 0,24 & Valid \\
\hline $\mathrm{X}_{2.4}$ & 0,861 & 0,24 & Valid \\
\hline $\mathrm{X}_{2.5}$ & 0,830 & 0,24 & Valid \\
\hline $\mathrm{X}_{3.1}$ & 0,535 & 0,24 & Valid \\
\hline $\mathrm{X}_{3.2}$ & 0,778 & 0,24 & Valid \\
\hline $\mathrm{X}_{3.3}$ & 0,644 & 0,24 & Valid \\
\hline $\mathrm{X}_{3.4}$ & 0,838 & 0,24 & Valid \\
\hline $\mathrm{X}_{3.5}$ & 0,724 & 0,24 & Valid \\
\hline $\mathrm{X}_{4.1}$ & 0,714 & 0,24 & Valid \\
\hline $\mathrm{X}_{4.2}$ & 0,898 & 0,24 & Valid \\
\hline$X_{4.3}$ & 0,902 & 0,24 & Valid \\
\hline $\mathrm{X}_{4.4}$ & 0,894 & 0,24 & Valid \\
\hline $\mathrm{X}_{4.5}$ & 0,794 & 0,24 & Valid \\
\hline $\mathrm{X}_{5.1}$ & 0,680 & 0,24 & Valid \\
\hline $\mathrm{X}_{5.2}$ & 0,498 & 0,24 & Valid \\
\hline $\mathrm{X}_{5.3}$ & 0,663 & 0,24 & Valid \\
\hline $\mathrm{X}_{5.4}$ & 0,620 & 0,24 & Valid \\
\hline $\mathrm{X}_{5.5}$ & 0,716 & 0,24 & Valid \\
\hline $\mathrm{Y}_{.1}$ & 0,773 & 0,24 & Valid \\
\hline $\mathrm{Y}_{.2}$ & 0,338 & 0,24 & Valid \\
\hline
\end{tabular}

$\begin{array}{llll}\mathrm{Y}_{.3} & 0,500 & 0,24 & \text { Valid } \\ \mathrm{Y}_{.4} & 0,811 & 0,24 & \text { Valid } \\ \mathrm{Y}_{.5} & 0,637 & 0,24 & \text { Valid }\end{array}$

Sumber: Data primer tahun 2019 diolah melalui SPSS V.21

Dari tabel uji validasi diatas, tergambarkan variabel pengetahuan, kemampuan berpikir, analisis tugas, pengalaman, tekanan waktu dan pendeteksi kecurangan memiliki nilai rhitung yang lebih besar dibandingkan dengan rtabel.. Sehingga dapat disimpulkan bahwan semua indikator atau koesioner yang digunakan pada setiap variabel valid.

c. Analisis Regresi Berganda

Untuk menganalisis sejauh mana pengaruh pengetahuan, kemampuan berpikir, analisis tugas, pengalaman, tekanan waktu dan pendeteksi kecurangan pada inspektorat Kabupaten Pinrang. dilakukan dengan menggunakan analisis regresi linear berganda. Analisis dilakukan berdasarkan nilai dari standardized coefficients hasil regresi antara pengaruh pengetahuan, kemampuan berpikir, analisis tugas, pengalaman, tekanan waktu dan pendeteksi kecurangan.Untuk lebih jelas akan disajikan hasil olahan data dengan menggunakan program statistical package for the social sciences (SPSS) pengetahuan, kemampuan berpikir, analisis tugas, pengalaman, tekanan waktu dan pendeteksi kecurangan:

Tabel 4. Hasil Olahan Data Regresi Coefficients $^{\mathrm{a}}$

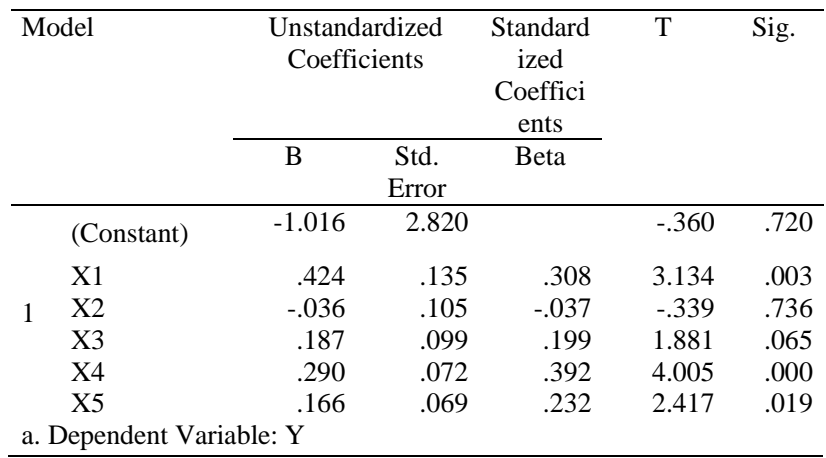

Dari hasil olahan diatas, maka dimasukkan data pada rumus regresi linear berganda sebagai berikut:

1. Konstanta (a) sebesar -1.016 artinya jika semua variabel bebas yaitu pengetahuan, kemampuan berpikir, analisis tugas, pengalaman, tekanan waktu dan pendeteksian kecurangan memiliki nilai 0 , maka pendeteksian kecurangan $\mathrm{Y}$ memiliki nilai sebesar -1.016.

2. Koefisien regresi (b1) untuk variabel pengetahuan $\mathrm{X} 1$ sebesar 0,424 artinya jika pengetahuan mengalami kenaikan sebesar 1 satuan, maka pendeteksian kecurangan (Y) akan mengalami peningkatan sebesar 0,424. Koefisien bernilai positif antara pengetahuan dan pendeteksi kecurangan.

3. Koefisien regresi (b2) untuk variabel kemampuan berpikir (X2) sebesar -0,36 artinya jika kerja mengalami kenaikan sebesar 1 satuan, maka 
pendeteksian kecurangan (Y) akan naik sebesar 0,36 .

4. Koefisien regresi (b3) untuk variabel analisis tugas (X3) sebesar 0,187 artinya jika kerja mengalami kenaikan sebesar 1 satuan, maka pendeteksian kecurangan (Y) akan naik sebesar 0,187.

5. Koefisien regresi (b4) untuk variabel pengalaman (X4) sebesar 0,290 artinya jika kerja mengalami kenaikan sebesar 1 satuan, maka pendeteksian kecurangan (Y) akan naik sebesar 0,290.

6. Koefisien regresi (b5) untuk variabel tekanan waktu (X5) sebesar 0,166 artinya jika kerja mengalami kenaikan sebesar 1 satuan, maka pendeteksian kecurangan (Y) akan naik sebesar 0,166.

Selanjutnya untuk mengetahui sejauh mana hubungan antara pengetahuan, kemampuan berpikir, analisis tugas, pengalaman, tekanan waktu dan pendeteksian kecurangan pada Inspektorat Kabupaten Pinrang.

\section{Tabel 5.. Nilai Koefisien Determinasi} Model Summary ${ }^{\mathrm{b}}$

\begin{tabular}{lccccc}
\hline Model & $\mathrm{R}$ & $\begin{array}{c}\mathrm{R} \\
\text { Squar } \\
\mathrm{e}\end{array}$ & $\begin{array}{c}\text { Adjusted R } \\
\text { Square }\end{array}$ & $\begin{array}{c}\text { Std. Error } \\
\text { of the } \\
\text { Estimate }\end{array}$ & $\begin{array}{c}\text { Durbin- } \\
\text { Watson }\end{array}$ \\
\hline 1 & $.783^{\mathrm{a}}$ & .613 & .581 & 1.21268 & 1.632 \\
\hline $\begin{array}{l}\text { a. Predictors: (Constant), X5, X3, X4, X1, X2 } \\
\text { b. Dependent Variable: Y }\end{array}$
\end{tabular}

Sumber: Data primer tahun 2020 diolah melalui SPSS V.21

Berdasarkan hasil analisis kolerasi yang dikutip pada table diatas, maka dapat dikatakan bahwa kolerasi atau hubungan antara pengetahuan, kemampuan berpikir, analisis tugas, pengalaman, tekanan waktu mempunyai hubungan yang cukup tinggi terhadap pendeteksian kecurangan di Inspektorat Kabupaten Pinrang karena diperoleh nilai koefisien kolerasi (r) sebesar 0,783.

d. Uji Hipotesis

Dari Tabel 5., diatas dapat dijelaskan bahwa: Pembuktian hipotesis yang di sajikan dalam penelitian ini dilakukan dengan melakukan pengujian terhadap hipotesis. Pengujian hipotesis dilakukan dengan menggunakan uji parsial (t) dan uji simultan (F) yang diuraikan sebagai berikut :

1) Uji Parsial t

Analisis uji parsial (t) dilakukan untuk membuktikan pengaruh signifikan antara variable independen (pengetahuan, kemampuan berpikir, analisis tugas, pengalaman, tekanan waktu) terhadap dependen (pendeteksi kecurangan).

Dengan melakukan perbandingan antara nilai $t$ hitung $\left(t_{\text {hitung }}\right)$ dan $t$ tabel $\left(t_{\text {tabel }}\right)$. Penunjukan diterimahnya hipotesis jika $t$ hitung lebih besar dari $t$ table $\left(t_{\text {hitung }}>\right.$ $\mathrm{t}_{\text {table }}$ ), $\mathrm{t}$ table $\left(\mathrm{t}_{\text {table }}\right)$ diperoleh dari banyaknya observasi dikurang banyaknya variable yang digunakan $(\mathrm{n}-\mathrm{k}-1)$, yaitu $65-6-1=58$, maka diketahui $\mathrm{t}$ table adalah 3.134. dimana derajat signifikan yang digunakan adalah lebih kecil $\alpha=0,05$, artinya nilai signifikan harus lebih kecil dari derajat kepercayaan $(\alpha)$ atau probabilitas. Untuk hasil yang dikelola, disajikan pada tabel berikut:
Tabel 6. Uji t coefficient

\begin{tabular}{c|r|r|r|r|l|l}
\hline \multirow{2}{*}{ Model } & \multicolumn{2}{|c|}{$\begin{array}{c}\text { Unstandardized } \\
\text { Coefficients }\end{array}$} & Stdrz & & & \\
\cline { 2 - 5 } & \multicolumn{1}{c|}{$\mathrm{B}$} & $\begin{array}{c}\text { Std, } \\
\text { Eror }\end{array}$ & Beta & $\begin{array}{c}\mathrm{t} \\
\text { hitung }\end{array}$ & \multicolumn{1}{c|}{ Sig, } & \multirow{2}{*}{ Keterangan } \\
\hline & -1.016 & 2.820 & & -360 & .720 & \\
X1 & .427 & .135 & .380 & 3.134 & .003 & Hipotesa diterima \\
X2 & -036 & 105 & -.037 & -.339 & .736 & Hipotesa diterima \\
X3 & 187 & .099 & .199 & 1.881 & .065 & Hipotesa diterima \\
X4 & 290 & .072 & .392 & 4.005 & .000 & Hipotesa diterima \\
X5 & 166 & .069 & .232 & 2.417 & .019 & Hipotesa diterima \\
\hline
\end{tabular}

a. Dependent Variable: Kinerja

Sumber: Data primer tahun 2020 diolah melalui SPSS

a) Pengetahuan $\left(X_{1}\right)$

Terlihat pada tabel coefficient tersebut bahwa derajat signifikan lebih kecil dari derajat kepercayaan atau probabilitas $(\mathrm{sig},<\alpha)=003<0,05$ maka hipotesis 1 diterima. Dimana $t_{\text {hitung }}$ lebih besar dari $\mathrm{t}_{\text {tabel }}\left(\mathrm{t}_{\text {hitung }}>\mathrm{t}_{\text {tabel }}\right)=3.134>2.340$ Terlihat bahwa variabel $\mathrm{X}_{1}$ memiliki kontribusi terhadap $\mathrm{Y}$. Nilai $\mathrm{t}$ positif menunjukkan bahwa variabel $X_{1}$ mempunyai hubungan yang searah dengan $\mathrm{Y}$. Sehingga dapat disimpulkan bahwa pengetahuan berpengaruh positif dan signifikan terhadap pendeteksian kecurangan.

b) Kemampuan berpikir $\left(\mathrm{X}_{2}\right)$

Terlihat pada tabel coefficient tersebut bahwa derajat signifikan lebih kecil dari derajat kepercayaan atau probabilitas $($ sig,$<\alpha)=0.736>0$, 05 maka hipotesis 2 diterima. Dimana $t_{\text {hitung }}$ lebih besar dari $t_{\text {tabel }}\left(t_{\text {hitung }}>t_{\text {tabel }}\right)=0.339<2.390$ terlihat variabel $\mathrm{X}_{2}$ memiliki kontribusi terhadap $\mathrm{Y}$. Nilai $\mathrm{t}$ positif menunjukkan bahwa variabel $X_{2}$ mempunyai hubungan yang searah dengan Y. Sehingga dapat disimpulkan bahwa pengetahuan tidak berpengaruh dan tidak signifikan terhadap pendeteksian kecurangan.

c) Analisis Tugas $\left(\mathrm{X}_{3}\right)$

Terlihat pada tabel coefficient tersebut bahwa derajat signifikan lebih kecil dari derajat kepercayaan atau probabilitas $(\mathrm{sig},<\alpha)=065>0,05$ maka hipotesis 3 diterima. Dimana $t_{\text {hitung }}$ lebih besar dari $t_{\text {tabel }}\left(t_{\text {hitung }}>t_{\text {tabel }}\right) 1.881<2.390$ Terlihat bahwa variabel $\mathrm{X}_{3}$ memiliki kontribusi terhadap $\mathrm{Y}$. Nilai $\mathrm{t}$ positif menunjukkan bahwa variabel $X_{3}$ mempunyai hubungan yang searah dengan Y. Sehingga dapat disimpulkan bahwa pengetahuan tidak berpengaruh dan tidak signifikan terhadap pendeteksian kecurangan.

d) Pengalaman $\left(\mathrm{X}_{4}\right)$

Terlihat pada tabel coefficient tersebut bahwa derajat signifikan lebih kecil dari derajat kepercayaan atau probabilitas (sig, $<\alpha)=000<0,05$ maka hipotesis 4 diterima. Dimana $t_{\text {hitung }}$ lebih besar dari $t_{\text {tabel }}\left(t_{\text {hitung }}>t_{\text {tabel }}\right) 4.005>2.390$ Terlihat bahwa variabel $\mathrm{X}_{4}$ memiliki kontribusi terhadap $\mathrm{Y}$. Nilai $\mathrm{t}$ positif menunjukkan bahwa variabel $X_{4}$ mempunyai hubungan yang searah dengan Y. Sehingga dapat 
disimpulkan bahwa pengetahuan berpengaruh positif dan signifikan terhadap pendeteksian kecurangan.

e) Tekanan Waktu $\left(\mathrm{X}_{5}\right)$

Terlihat pada tabel coefficient tersebut bahwa derajat signifikan lebih kecil dari derajat kepercayaan atau probabilitas $(\mathrm{sig},<\alpha)=0.019$ $<0,05$ maka hipotesis 4 diterima. Dimana $t_{\text {hitung }}$ lebih besar dari $t_{\text {tabel }}\left(t_{\text {hitung }}>t_{\text {tabel }}\right) 2.417>2.390$ Terlihat bahwa variabel $\mathrm{X}_{5}$ memiliki kontribusi terhadap Y. Nilai $\mathrm{t}$ positif menunjukkan bahwa variabel $\mathrm{X}_{5}$ mempunyai hubungan yang searah dengan $\mathrm{Y}$. Sehingga dapat disimpulkan bahwa pengetahuan tidak berpengaruh dan tidak signifikan terhadap pendeteksian kecurangan.

2) Uji Simultan

Uji $F$ digunakan untuk mengetahui pengaruh variabel independen secara serentak terhadap variabel dependen, Dalam penelitian ini variabel independen terdiri dari pengetahuan $\left(\mathrm{X}_{1}\right)$, kemampuan berpikir $\left(\mathrm{X}_{2}\right)$, analisis tugas $\left(\mathrm{X}_{3}\right)$, pengalaman $\left(\mathrm{X}_{4}\right)$ dan tekanan waktu $\left(\mathrm{X}_{5}\right)$. sedangkan variabel dependen adalah pendeteksian kecurangan (Y). Untuk mengetahui apakah hipotesis diterima atau tidak, maka $\mathrm{F}$ hitung harus lebih besar dari $\mathrm{F}$ tabel $\left(\mathrm{F}_{\text {hitung }}>\mathrm{F}_{\text {tabel }}\right)$ melaui sig, $\alpha=0,05$.

Hasil uji $\mathrm{F}$ antara pengetahuan $\left(\mathrm{X}_{1}\right)$, kemampuan berpikir $\left(\mathrm{X}_{2}\right)$, analisis tugas $\left(\mathrm{X}_{3}\right)$, pengalaman $\left(\mathrm{X}_{4}\right)$, tekanan waktu $\left(\mathrm{X}_{5}\right)$ terhadap pendeteksian kecurangan (Y) dapat dilihat tabel anova hasil perhitungan dari SPSS sebagai berikut:

\begin{tabular}{llrrrrr}
\multicolumn{8}{c}{ ANOVA $^{\mathbf{a}}$} \\
\hline Model & $\begin{array}{c}\text { Sum of } \\
\text { Squares }\end{array}$ & df & $\begin{array}{c}\text { Mean } \\
\text { Square }\end{array}$ & F & Sig. \\
\hline \multirow{2}{*}{1} & Regression & 139.703 & 5 & 27.941 & 18.999 & $.000^{\mathrm{b}}$ \\
\cline { 2 - 7 } & Residual & 88.236 & 60 & 1.471 & & \\
\cline { 2 - 7 } & Total & 227.939 & 65 & & &
\end{tabular}

a. Dependent Variable: Y

b. Predictors: (Constant), X5, X3, X4, X1, X2

Untuk membuktikan Hipotesis penelitian yang telah diketahui sebelumnya dapat dilihat berdasarkan Tabel 4 . diketahui bahwa nilai $\mathrm{F}$ hitung sebesar 18.999. Maka dapat lihat bahwa $\mathrm{F}$ hitung lebih besar dari $\mathrm{F}$ tabel $\left(\mathrm{F}_{\text {hitung }}\right.$ $\left.>\mathrm{F}_{\text {tabel }}\right) 18.999>$ 3112. Dengan demikian hipotesis penelitian diterima, artinya variabel pengetahuan, kemampuan berpikir, analisis tugas, pengalaman, tekanan waktu secara bersama-sama (simultan) berpengaruh secara positif dan signifikan terhadap pendeteksian kecurangan di Inspektorat Kabupaten Pinrang.

Secara umum hasil penelitian ini memuaskan. Segala hipotesis yang digambarkan diterima berdasalkan analisis hasil jawaban responden pada Inspektorat Kabupaten Pinrang.

1. Pengaruh pengetahuan terhadap pendeteksian kecurangan

Dari hasil analisis persamaan regresi maka diperoleh hasil bahwa variabel pengetahuan berpengaruh positif dan signifikan terhadap pendeteksian kecurangan oleh Inspektorat Kabupaten Pinrang.
2. Pengaruh kemampuan berpikir terhadap pendeteksian kecurangan

Dari hasil analisis persamaan regresi maka diperoleh hasil bahwa variabel kemampuan berpikir tidak berpengaruh dan tidak signifikan terhadap pendeteksian kecurangan oleh Inspektorat Kabupaten Pinrang.

3. Pengaruh analisis tugas terhadap pendeteksian kecurangan

Dari hasil analisis persamaan regresi maka diperoleh hasil bahwa variabel analisis tugas tidak berpengaruh dan tidak signifikan terhadap pendeteksian kecurangan oleh Inspektorat Kabupaten Pinrang.

4. Pengaruh pengalaman terhadap pendeteksian kecurangan

Dari hasil analisis persamaan regresi maka diperoleh hasil bahwa variabel pengalaman berpengaruh positif dan signifikan terhadap pendeteksian kecurangan oleh Inspektorat Kabupaten Pinrang.

5. Pengaruh tekanan waktu terhadap pendeteksian kecurangan

Dari hasil analisis persamaan regresi maka diperoleh hasil bahwa variabel tekanan waktu berpengaruh positif dan signifikan terhadap pendeteksian kecurangan oleh Inspektorat Kabupaten Pinrang.

6. Pengaruh pengetahuan, kemampuan berpikir, analisis tugas, pengalaman, tekanan waktu terhadap pendeteksian kecurangan.

Pengeloaan data regresi berganda yang dilakukan dalam penelitian ini memberikan hasil bahwa pengetahuan, kemampuan berpikir, analisis tugas, pengalaman, tekanan waktu berpengaruh positif dan signifikan terhadap pendeteksian kecurangan oleh Inspektorat Kabupaten Pinrang.

\section{KESIMPULAN DAN SARAN}

Hasil penelitian menyimpulkan bahwa pengaruh variabel pengetahuan berpengaruh positif dan signifikan terhadap pendeteksian kecurangan oleh Inspektorat Kabupaten Pinrang. Pengaruh variabel kemampuan berpikir tidak berpengaruh dan tidak signifikan terhadap pendeteksian kecurangan oleh Inspektorat Kabupaten Pinrang. Pengaruh variabel analisis tugas tidak berpengaruh dan tidak signifikan terhadap pendeteksian kecurangan oleh Inspektorat Kabupaten Pinrang. Pengaruh variabel pengalaman berpengaruh positif dan signifikan terhadap pendeteksian kecurangan oleh Inspektorat Kabupaten Pinrang. Pengaruh variabel tekanan waktu tidak berpengaruh dan tidak signifikan terhadap pendeteksian kecurangan oleh Inspektorat Kabupaten Pinrang.

\section{DAFTAR PUSTAKA}

Abdolmohammadi, M.J., 1991. Factor Affecting Auditor's Perceptions of Applicable Decision Aids for Various 
Audit Task, "Contemporary Accounting Research 7 no. 2 hal. 535-548.

Achmad, J., Saleh, H., \& Chahyono, C. (2021). Akuntabilitas, Transparansi Dan Partisipasi Penyusunan Anggaran Terhadap Kinerja Anggaran Pada Pemerintah Daerah Luwu Timur. Indonesian Journal of Business and Management, 2(2), 105111.

Agoes, Sukrisno, 2004. Auditing (Pemeriksaan Akuntan) oleh Kantor Akuntan Publik, Lembaga Penerbit: FEUI, Jakarta

Akmal, 2006. Pemeriksaan Intern, Penerbit: Indeks, Jakarta.

Albrechtet, 2012. Asset Misappropriation Research White Paper for the Institute for Fraud Prevention.

Amrizal, 2004, "Pencegahan dan Pendeteksian kecurangan oleh internal auditor". BPKP.

Anggriawan, Eko Ferry, 2014. Pengaruh Pengalaman Kerja, Skeptisme Profesional dan Tekanan Waktu Terhadap Kemampuan Auditor dalam Mendeteksi Fraud (Studi Empiris pada Kantor Akuntan Publik Di DIY). Jurnal Nominal Vol.III No.2, 2014.

Anthony, Robert N., Vijay Govindarajan, 2005. Sistem Pengendalian Manajemen, edisi kesebelas, Penerbit: Salemba Empat, Jakarta.

Arens, A., Mark S. Beasley, Randal J. Elderand Amir Abadi Jusuf, 2011. Auditing and Assurance Service: An Integrated Approach. Edisi keduabelas, Penerbit: Salemba Empat, Jakarta.

Arens, A. Alvin dan James K. Loebbecke, 2003. Auditing (Suatu Pendekatan Terpadu), edisi Keenam, Penerbit Erlangga, Jakarta

Arifah, Dista Amalia, 2012, Praktek Teori Egensi pada Entitas Publik dan Non Publik, Prestasi Vol.9 No.1 Juni 2012, ISSN 1411-1497.

Armstrong, J. Scott, 2005. Demand Forecasting Using Evidence-based Principles, Presentation, Teheran, 21 January 2009.

Arthur, W. Holmes, David C. Burns, 2008. Auditing Norma dan Prosedur. Alih Bahasa Moh. Badjuri, edisi kesembilan. Jilid Satu. Penerbit: Erlangga, Jakarta.

Ashton, A.H. (1991). Experience and Error Frequency Knowledge as Potential Determinants of Audit Expertise. The Accounting Review, 66,2,218

Ayura, Dies Pra, 2013. Pengaruh Latar Belakang Pendidikan, Pendidikan Berkelanjutan, Komitmen Organisasi, dan Pengalaman Kerja terhadap Kinerja aparat Pengawas Intern Pemerintah (APIP) pada Inspektorat Provinsi Sumatera Barat, Universitas Negeri Padang, Padang.

BPKP, 2008. Kode Etik dan Standar audit, Jurnal Pembentukan Auditor Ahli, Edisi 5, Jakarta.

BPKP, 2014, Ihtisar Hasil Pemeriksaan Semester I Tahun 2014, Pemeriksaan Laporan Keuangan, Buku II, Jakarta.

Bonner, S.E., Lewis, B.L. 1990. Determinants of Auditor Expertise. Journal of Accounting Research, 28, 1-20

Bouman, Marinus J, dan Bradley Wray E (1997). Judgement and Decision Making, Part II: Expertise, Consensus and Accuracy, Behaviour Accounting Research: Fondation and Frontiers, American Accounting Association, Pg. 89 - 123

Bowrin, Anthony R dan James King II, 2009. "Time Pressure, Task Complexity. And Audit Effectiveness". Managerial Auditing Journal. Vol 25 No.2 (160-181).

Boynton, William C., Johnson, Raymond N., and Kell, Walter G. (2001). Modern Auditing. 7 th Edition. John Willey \& Sons Inc, New York.

DeAngelo, L.E. 1981. Auditor Size and Audit Quality, Journal of Accounting and Economics 3 (1): 167-175

Digman, J. M., \& Takemoto-Chock, N. K. (1991). Factors in the natural language of personality: Re-analysis, comparison, and interpretation of six major studies. Multivariate Behavioral Research, 16, 149-170

Emerson, David J. dan Ling Yang, 2012. "Perception of Auditor Conscientiousness and Fraud Detection", Jurnal of Forensic \& Investigative Accounting, Volume 4 issue 2, halaman 110-141.

Goldman, A. and B. Barlev, 1974. The Auditor-Firm Conflict of Interests: Its Implications for Independence. The Accounting Review 49 (4): 707-718.

Ghozali, Imam, 2009. Aplikasi Analisis Multivariate dengan Program SPSS. edisi ketiga. Semarang: Badan Penerbit Universitas Diponegoro.

Hafifah Nasution dan Fitriany, (2012). Pengaruh Beban Kerja, Pengalaman Audit dan Tipe Kepribadian Terhadap Skeptisme Profesional dan Kemampuan Auditor Dalam Mendeteksi Kecurangan. Jurnal.

Halim Abdul, 2004. Auditing 1 Dasar-Dasar Audit Laporan Keuangan, Unit Penerbit dan Percetakan AMP YKPN, Yogyakarta

Hassink, Harold, Meuwissen, Roger dan Bollen, Laury, 2010. Fraud Detection, Redress and Reporting by Auditors. Managerial Auditing Journal, Vol. 25 No. 9, pp. 861-881.

IBK, Bayangkara, 2011. Audit Manajemen, Prosedur dan Implementasi, cetakan keenam, Penerbit: Salemba Empat, Jakarta.

Indriasih, Dewi, 2013. The Effect of Government Apparatus Competence and the Effectiveness of Government Internal Control Toward the Quality of Financial Reporting in Local Goverment, Research Journal of Finance and Accounting, Accounting Doctoral Program Faculty of Economic and Business Padjadjaran University-Indonesia

Jensen, M. C and Meckling, W.H. 2006. Theory of the Firm: Managerial Behavior, Agency Costs and Ownership Structure. Journal of Financial Economics, Oktober, 1976, V. 3, No. 4, pp. 305-360. Avalaible from: http://papers.ssrn.com (Diakses 20 Maret 2015).

Jordan Matodan, 2010. Pengaruh Pengalaman Audit, Independensi, dan Keahlian Profesional Terhadap Pencegahan dan Pendeteksian Kecurangan Penyajian Laporan Keuangan (Studi Empiris Pada Kantor Akuntan Publik di DKI Jakarta).

James D. Willson and John B. Campbell, Controllership, 2003. Akuntan Manajemen, edisi ketiga, Terjemahan 
Tjin Thia. Felix H. Tjendera, Penerbit : Erlangga, Jakarta.

Karni, Soejono, 2003. Auditing, Lembaga Penerbit: Fakultas Ekonomi Universitas Indonesia, Jakarta.

Karyono, 2013. Forensic Fraud, Edisi I, Yogyakarta: Andi.

Koroy, Tri R, 2008. Pendeteksian Kecurangan (Fraud) Laporan Keuangan oleh Auditor Eksternal, Jurnal Akuntansi dan Keuangan, Vol. 10, No.1.

Kumaat Valey G, 2011. Internal Audit, edisi pertama, cetakan keempatbelas, Penerbit : Erlangga, Jakarta

Kosasih Ruchyat, 2005. Auditing Prinsip dan Prosedur, Buku satu, Penerbit Palapa, Surabaya

Lisa Amelia Herman, 2013. Pengaruh Keadilan Organisasi dan Sistem Pengendalian Intern Terhadap Kecurangan (Studi Empiris pada Kantor Cabang Utama Bank Pemerintah di Kota Padang). Universitas Negeri Padang.

Lastanti, Hexana Sri, 2005. Tinjauan Terhadap Kompetensi dan Independensi Akuntan Publik: Refleksi Atas Skandal Keuangan. Media Riset Akuntansi, Auditing dan Informasi Vol.5 No.1 April 2005. Hal 85-97

Libby, R., Frederick, D.M. (1990). Experience and the ability to explain audit findings. Journal of Accounting Research 28, 348-67

Lowensohn, 2007. Auditor Specialization, Perceived Audit Quality, and Audit Fees in The Local Government Audit Market. Journal of Accounting and Public 26, Elsivier.

LAN, BPKP, 2008. Pengukuran Kinerja Instansi Pemerintah, Modul Sosialisasi Sistem Akuntanbilitas Kinerja Instansi Pemerintah (AKIP), Jakarta : Lembaga Administrasi Negara.

Lestari, A. P. 2010. Faktor-faktor yang Mempengaruhi Perilaku Auditor Dalam Penghentian Prematur Prosedur Audit. Jurnal, Ekonomi Universitas Diponegoro semarang

Mardisar, Diani dan Sari, Nelly, 2007. Pengaruh Akuntabilitas dan Pengetahuan Terhadap Kualitas Hasil Kerja Auditor. SNA X Makasar. AUEP-11. 1-25

Marpaung, Leden, 2004. Tindak Pidana Korupsi Pemberantasan dan Pencegahan, Edisi Revisi II, Djambatan, Jakarta.

Masdupi, Erni, 2005. Analisis Dampak Struktur Kepemilikan Pada Kebijakan Hutang Dalam Mengontrol Konflik Keagenan, Journal Ekonomi dan Bisnis Indonesia, Vol. 20, No.1 : 57 - 69.

Mayangsari, Sekar, 2003. "Analisis Pengaruh Independensi, Kualitas Audit, serta Mekanisme Corporate Governance terhadap Integritas Laporan Keuangan". Simposium Nasional Akuntansi VI Surabaya, Oktober.

Mulyadi, Puradiredja, Kanaka, 2002. Auditing Jilid satu. edisi keenam, Penerbit : Salemba Empat, Jakarta

Murtanto \& Gudono, 1999. Identifikasi KarakteristikKarakteristik Keahlian Audit: Profesi Akuntan Publik di Indonesia. Jurnal Riset Akuntansi Indonesia, 2 (Januari), 37 - 52.
Menteri Pendayagunaan Aparatur Negara (Menpan) Nomor: PER/M.PAN/ 03.2008, tentang Standar Audit Aparat Pengawas Intern Pemerintah.

Menteri Pendayagunaan Aparatur Negara (Menpan)Nomor 15 Tahun 2009 tentang Jabatan Fungsional Pengawas Penyelenggaraan Urusan Pemerintah di Daerah dan Angka Kreditnya.

Nadirsyah dan Intan Maulida Zuhra, 2009. Locus Of Control, Time Budget Pressure dan Penyimpangan Perilaku dalam Audit. Jurnal Telaah \& Riset Akuntansi, 7 (2) Vol. 2: 104-116.

Nichols, D. R. and K. H. Price, 1976. The Auditor Firm Conflict: An Analysis Using Concepts Of Exchange Theory. The Accounting Review. April.

Pangestika, Widya, 2014. Pengaruh Keahlian Profesional, Independensi dan Tekanan Anggaran Waktu terhadap Pendeteksian Kecurangan (Studi Empiris pada BPKPPerwakilan Provinsi Riau), Universitas Riau, Pekanbaru.

Peraturan Menteri Dalam Negeri Republik Indonesia Nomor 47 Tahun 2011 tentang Kebijakan Pengawasan di Lingkungan Kementerian Dalam Negeri dan Penyelenggaraan Pemerintahan Daerah Tahun 2012.

Peraturan Pemerintah Republik Indonesia No. 79 Tahun 2005 tentang Pedoman Pembinaan dan Pengawasan Penyelenggaraan Pemerintahan Daerah.

Pertiwi, Eka Putri, 2010. Analisis Pengaruh Komponen Keahlian Internal Auditor Terhadap Pendeteksian dan Pencegahan Kecurangan (Fraud) di Inspektorat Jenderal Kementerian Perdagangan Republik Indonesia. Universitas Negeri Syarif Hidayatullah, Jakarta.

Poerwadarminta, W.J.S, 2006. Kamus Umum Bahasa Indonesia. Jakarta: Balai Pustaka.

Purwanto, Agus, Erwan dan Dyah Ratih Sulistyastuti, Metode Penelitian Kuantitatif, Untuk Admnisitrasi Publik, dan Masalah-masalah Sosial, 2007, Gaya Media Jogyakarta.

Rahayu Siti Kurnia dan Ely Suhayati, 2010. Auditing Konsep Dasar dan Pedoman Pemeriksaan Akuntan Publik, Penerbit: Graha Ilmu, Jakarta.

Shanteau,J., 1988. "Psychological Characteristic of Expert Decision Makers”, Acta Psychologica 68, hal. 289-304.

Silaban, Adanan, 2011. Pengaruh Multidimensi Komitmen Profesional Terhadap Perilaku Audit Disfungsional. Jurnal Akuntansi \& Auditing. Vol. 8. No. 1.

Singleton, W. Tommie Aaron, 2010. Fraud Auditing ND Forensic Accounting, Fourth Edition, New York.

Sososutikno, Christina, 2003. "Hubungan Tekanan Anggaran Waktu dengan Perilaku Disfungsional serta Pengaruhnya terhadap Kualitas Audit", Somposium Nasional Akuntansi VI, Surabaya.

Sunarto, 2003. Auditing, Penerbit : Panduan, Yogyakarta

Sunyoto Danang, 2012. Analisis Validitas dan Asumsi Klasik, cetakan pertama, Penerbit: Gava Media, Yogyakarta

Susetyo, Budi, 2009. Pengaruh Pengalaman Audit terhadap Pertimbangan Auditor dengan Kredibilitas Klien 
sebagai Variabel Moderating. Tesis Universitas Diponegoro : Semarang.

Tugiman, Hiro, 2006. Standar Profesional Audit Internal. cetakan kesembilan, Penerbit: Kanisius, Yogyakarta

Tunggal, Amin Widjaja, 2001. Audit Kecurangan, Suatu Pengantar, Penerbit : Harvarindo, Jakarta

Tunggal, Amin Widjaja, 2003. Audit Laporan Keuangan, (Financial Statement Audit), Penerbit: Harvarindo, Jakarta

Tuanakotta.M. Theodorus, 2007. Akuntansi Forensik dan Audit Investigasi, Lembaga Fakultas Ekonomi Universitas Indonesia, Jakarta

Valery G. Kumaat, 2011. Internal audit, Jakarta: Penerbit Erlangga.

Wardani, IGK, 2014. Pemantapan Kemampuan Profesional, Jakarta, Universitas Terbuka.

Wardhani, Fatima Nurita, 2014. Pengaruh Komponen Keahlian Auditor Dalam Mendeteksi Kecurangan (Studi Empiris pada Eksternal Auditor di Semarang). Universitas Diponegoro Semarang

Wells, Joseph T. 2005. Principles of Fraud Examination. John Willey \& Sons,Inc

Yosua, Rikarbo Rekkat. 2012. Faktor-faktor yang Mempengaruhi Penghentian Prematur atas Prosedur Audit. Unri: Pekanbaru. 